\title{
PRWHE-skjemaet på norsk - vurdering av hånd- og håndleddsplager
}

\author{
Et evalueringsverktøy for hånd- og håndleddsplager har lenge vært etterspurt på norsk. Nå er Patient Rated \\ Wrist and Hand Evaluation oversatt til norsk, og skjemaet er gratis tilgjengelig for alle.
}

Ved ufarlige, men smertefulle og funksjonsreduserende tilstander bør effekten av oppfølging og behandling evalueres og om mulig kvantifiseres. Dette gjelder med få unntak all ortopedisk og håndkirurgisk behandling. Tradisjonelt har evaluering av tilfredshet, leddutslag, kraft og radiologisk resultat vært hovedmål for klinikeren, men dette har ikke alltid vært i samsvar med pasientens vurdering.

Det er utviklet skåringsskjemaer for en rekke lidelser eller anatomiske regioner, og i de fleste publiserte studier som omhandler bevegelsesapparatet er det brukt ett eller flere. Slike evalueringsskjemaer må være relevante for pasienten, enkle å forstå, være raske å fylle ut for å sikre komplett utfylling (en forutsetning for å regne ut skåren) og gi høy svarprosent. For undersøkeren må skjemaene være klinisk relevante og kunne påvise viktige endringer i tilstanden uten å påvirkes for mye av andre plager/lidelser/ forhold. De må også være enkle å administrere i den kliniske hverdagen.

Evalueringsskjemaer er enten generiske (evaluerer pasientens komplette helsetilstand), sykdomsspesifikke (for oppfølging av spesielle lidelser), leddspesifikke eller regionspesifikke (f.eks. for overekstremitetene). De fleste skjemaer er utviklet for å påvise variasjon i pasientens tilstand over tid, oftest før og etter behandling (1). Brukt i retrospektive studier uten preoperativ skåring gir de mindre informasjon og bør da ikke benyttes for å sammenlikne nytten av forskjellige behandlinger.

Selv om de subjektive pasientvurderte skjemaene har begrensninger, gir de en kvantifisering som kan brukes til å vurdere effekten av en behandling og en mulighet for sammenlikning av forskjellige behandlingsformer for samme lidelse. Det er imidlertid viktig at alle benytter det samme validerte og korrekt oversatte skjemaet for at resultater skal kunne sammenliknes.

\section{Patient Rated Wrist and Hand Evaluation (PRWHE)}

For arm- og håndplager har DASH (Disability of Arm, Shoulder and Hand) (2) vært mye brukt. Skjemaet ble introdusert i 1996, og består av 30 spørsmål rettet mot symptomer og problemer med å utføre og delta i ulike fysiske og sosiale aktiviteter. DASH-skjemaet er oversatt til norsk og validert (3). Kortversjonen Quick-DASH med 11 av de opprinnelige spørsmålene kan brukes for å øke svarprosenten (4). En for- del med DASH-skjemaet er at overekstremitetene der ses som en helhet der problemer i ett anatomisk område påvirker andre områder. Den viktigste begrensningen er at andre lidelser/plager i samme eller motsatte arm vil kunne «forurense» behandlingsresultatet man er ute etter å evaluere.

De fleste skader og mange av de hyppigst opererte plager i overekstremitetene er lokalisert til hånd og håndledd. Et evalueringsverktøy som er begrenset til hånd og

\section{«For å kunne sammen- likne resultater påtvers av land og språkgren- ser er det viktig at utenlandske skjemaer oversettes slik at inten- sjonen med spørs- målene beholdes»}

håndledd har derfor vært etterspurt i Norge. Det kanadiske spørreskjemaet Patient Rated Wrist and Hand Evaluation (PRWHE) er et slikt verktøy $(5,6)$.

Skjemaet er utviklet for å kartlegge grad $\mathrm{av}$ hånd- $\mathrm{og}$ håndleddsrelatert smerte $\mathrm{og}$ funksjonsbegrensning. Det er todelt og består av én smertedel med fem spørsmål og én funksjonsdel med ti spørsmål. Spørsmålene besvares på en numerisk skala fra 0 til 10, der 0 betyr ingen smerter eller vansker og 10 verst tenkelige smerter eller noe pasienten ikke klarer å utføre. Smerte og funksjon vektes likt ved at funksjonspoengene deles på 2 , og man får en totalsum på mellom 0 og 100 . En endring på $>20$ poeng indikerer en klinisk viktig forskjell, mens en endring $<10-12$ poeng har lite eller ingen betydning $(7,8)$.

Ved at det også er rettet mot aktivitetsområder, fanger man ved hjelp av skjemaet opp funksjonsreduksjon hvor manglende utholdenhet er del av problemet, for eksempel ved repetitive bevegelser/belastninger $i$ arbeidssituasjoner og fritidssysler. DASHskjemaet og de fleste andre spørreskjemaer fanger ikke opp dette aspektet. PRWHEskjemaet er validert og oversatt til en rekke språk. Det er selvforklarende og raskt å besvare (ca. $7 \mathrm{~min}$ ). Det blir nå benyttet i de fleste prospektive studier som omhandler håndledd og hånd $(9,10)$.

For å kunne sammenlikne resultater på tvers av land og språkgrenser er det viktig at utenlandske skjemaer oversettes slik at intensjonen med spørsmålene beholdes - det vil si med en adaptasjon der man tar hensyn til kulturelle forskjeller. Vi har gjort en slik krysskulturell oversettelse av PRWHE-skjemaet basert på anbefalinger fra Beaton og medarbeidere (11). Prosessrapporten og den offisielle norske oversettelsen er godkjent av den kanadiske gruppen som har opphavsrett til skjemaet.

Skjemaet er gratis tilgjengelig for alle interesserte som appendiks til denne artikkelen (www.tidsskriftet.no/reigstadappendiks), på hjemmesidene til Norsk forening for håndkirurgi (12), på sidene til Norsk forening for håndterapi (13) og på den internasjonale hjemmesiden for arbeidsgruppen bak skjemaet. Der er det også en omfattende brukermanual med bakgrunnsdokumentasjon tilgjengelig (14).

\author{
Ole Reigstad \\ ole.reigstad@gmail.com \\ Tone Vaksvik \\ Teresa Lütken \\ Jorun Bergt
}

Ole Reigstad (f. 1969) er ph.d., spesialist i ortopedisk kirurgi og overlege ved Håndog mikrokirurgisk seksjon, Ortopedisk avdeling, Oslo universitetssykehus, Rikshospitalet. Forfatter har fylt ut ICMJE-skjemaet og oppgir ingen interessekonflikter.

Tone Vaksvik (f. 1961) har en mastergrad i helsefagvitenskap og er ergoterapeut ved Seksjon for klinisk service ortopedi, Oslo universitetssykehus, Rikshospitalet.

Forfatter har fylt ut ICMJE-skjemaet og oppgir ingen interessekonflikter.

Teresa Lütken (f. 1947) er spesialfysioterapeut og jobber med håndterapi ved Seksjon for klinisk service ortopedi, Oslo universitetssykehus, Rikshospitalet.

Forfatter har fylt ut ICMJE-skjemaet og oppgir ingen interessekonflikter. 
Jorun Anita Berg (1961-2010) hadde en mastergrad i helsefagvitenskap og var fysioterapeut ved Seksjon for klinisk service ortopedi, Oslo universitetssykehus, Rikshospitalet.

\section{Litteratur}

1. Gummesson C, Atroshi I, Ekdahl C. The disabilities of the arm, shoulder and hand (DASH) outcome questionnaire: longitudinal construct validity and measuring self-rated health change after surgery. BMC Musculoskelet Disord 2003; 4: 11.

2. Hudak PL, Amadio PC, Bombardier C. Development of an upper extremity outcome measure: the DASH (disabilities of the arm, shoulder and hand) [corrected]. Am J Ind Med 1996; 29: 602-8.

3. Finsen V. Norsk versjon av DASH-skjemaet for undersøkelse av arm, skulder og hånd. Tidsskr Nor Legeforen 2008; 128: 1070.

4. Aasheim T, Finsen V. The DASH and the QuickDASH instruments. Normative values in the general population in Norway. J Hand Surg Eur Vol 2013. E-publisert 20.3

5. MacDermid JC, Turgeon T, Richards RS et al. Patient rating of wrist pain and disability: a reliable and valid measurement tool. J Orthop Trauma 1998; 12: 577-86.
6. MacDermid JC, Tottenham V. Responsiveness of the disability of the arm, shoulder, and hand (DASH) and patient-rated wrist/hand evaluation (PRWHE) in evaluating change after hand therapy. J Hand Ther 2004; 17: 18-23.

7. Hemelaers L, Angst F, Drerup S et al. Reliability and validity of the German version of «the Patientrated Wrist Evaluation (PRWE)» as an outcome measure of wrist pain and disability in patients with acute distal radius fractures. J Hand Ther 2008; $21: 366-76$

8. Schmitt JS, Di Fabio RP. Reliable change and minimum important difference (MID) proportions facilitated group responsiveness comparisons using individual threshold criteria. J Clin Epidemiol 2004; 57: $1008-18$.

9. Mellstrand Navarro C, Ponzer S, Törnkvist $\mathrm{H}$ et al. Measuring outcome after wrist injury: translation and validation of the Swedish version of the patientrated wrist evaluation (PRWE-Swe). BMC Musculoskelet Disord 2011; 12: 171

10. Schonnemann JO, Hansen TB, Soballe K. Translation and validation of the Danish version of the Patient Rated Wrist Evaluation questionnaire. J Plast Surg Hand Surg 2013. E-publisert 18.4.

11. Beaton DE, Bombardier C, Guillemin F et al. Guidelines for the process of cross-cultural adaptation of self-report measures. Spine 2000; 25: 3186-91.
12. Norsk forening for håndkirurgi. https://legeforeningen.no/spesial/ Norsk-forening-for-handkirurgi/ (27.9.2013)

13. Norsk forening for håndterapi. http://www.handterapi.no/handterapi/faglig/ (27.9.2013).

14. McMaster University Musculoskeletal Resource Center. www.srs-mcmaster.ca/Research Resourcesnbsp/ResearchThemes/Musculoskeletal/ DevelopmentEvaluationofMeasures/tabid/2726/ Default.aspx (27.9.2013).

Mottatt 6.9. 2013, første revisjon innsendt 26.9. 2013, godkjent 27.9. 2013. Redaktør Hanne Støre valeur. Engelsk oversettelse på www.tidsskriftet.no

Publisert først på nett.

Appendiks på www.tidsskriftet.no/ reigstadappendiks 